\title{
EFEKTIFITAS KOLOM DENGAN TULANGAN COLD-FORMEDTYPE HOLLOW DALAM MEMIKUL BEBAN AKSIAL
}

\author{
K. Budi Hastono \\ Program Studi Teknik Sipil, Fakultas Teknik, Universitas DR. Soetomo Surabaya, \\ Jl. Semolowaru No. 84 Surabaya, 60111 \\ budihastono@gmail.com
}

\begin{abstract}
As part of the support component in the building structure, the column is a component that bears an external load and it will give rise to axial force, bending moment and shear force along its height. Pure concrete columns can support very small loads, but their load carrying capacity will increase considerably if added longitudinal bars. Larger strength enhancements can be made by providing lateral restraints in this longitudinal reinforcement. As a result of the compressive load, the column tends not only to shorten in the longitudinal direction but also expands in the lateral direction due to the poison's effect. This research will be carried out by testing the maximum axial load until the crack occurs in the reinforced concrete column with the planning of the two looks, the $20 \times 20 \times 60 \mathrm{~cm}$ column size with the dependent variable of longitudinal steel screw and Cold Formed (mild steel) type hollow steel. The results of this study The use of the column by using screw steel reinforcement is still more effective than by using cold-formed steel reinforcement. Columns with reinforced steel reinforcement have a lower strength of $44.4 \%$ of the column by using screw steel reinforcement.
\end{abstract}

Keywords: Column, axial, cold-formed

\begin{abstract}
Abstrak
Sebagai bagian dari komponen penyokong dalam struktur bangunan, kolom merupakan komponen yang memikul beban luar dan itu akan menimbulkan gaya aksial, momen lentur dan gaya geser disepanjang ketinggiannya. Kolom beton murni dapat mendukung beban sangat kecil, tetapi kapasitas daya dukung bebannya akan meningkat cukup besar jika ditambahkan tulangan longitudinal. Peningkatan kekuatan yang lebih besar dapat dibuat dengan memberikan kekangan lateral pada tulangan longitudinal ini. Akibat beban tekan, kolom cenderung tidak hanya memendek dalam arah memanjang tetapi juga mengembang dalam arah lateral karena pengaruh poison. Penelitian ini akan dilakukan pengujian beban aksial maximum sampai terjadi retak pada kolom beton bertulang dengan perencanaan tampang dua, ukuran kolom 20 × 20 x $60 \mathrm{~cm}$ dengan variabel dependen tulangan longitudinal baja ulir dan tulangan Cold Formed ( baja ringan ) type hollow. Hasil dalam penelitian ini Penggunaan kolom dengan menggunakan tulangan baja ulir masih lebih efektif dari pada dengan menggunakan tulangan baja cold-formed. Kolom dengan tulangan baja col-formed mempunyai kekuatan lebih rendah 44, $4 \%$ dari kolom dengan menggunakan tulangan baja ulir.
\end{abstract}

Kata Kunci: Kolom, axial, cold-formed

\section{PENDAHULUAN}

Kolom sebagai elemen yang berfungsi sebagai penyokong dan memikul beban aksial tekan maupun tarik dengan perbandingan dari tinggi terhadap ukuran sisi terkecil yang tidak kurang dari 3 . Kolom beton bertulang pada prinsipnya terdiri dari dua macam, yang digolongkan menurut cara bangaimana batang tulangan longitudinal di tumpu dalam arah lateral. Kolom dengan pengikat, biasanya berbentuk bujur sangkar, persegi atau lingkaran, adalah jenis kolom dimana tulangan utama memanjang di pasang dalam kedudukannya oleh pengikat lateral terpisah yang umumnya ditempatkan dengan jarak 12 sampai 24 inchi.

Unsur struktur yang dibebani aksial, dengan atau tanpa kombinasi dengan lentur sering memikul bagian yang lebih besar dari beban tetap, akibatnya pengalihan beban dari beton ke tulangan akibat deformasi yang tergantung pada waktu.
Permasalahan yang terjadi pada penelitian ini adalah :

- Seberapa besar kemampuan cold formed type hollow sebagai tulangan pada elemen kolom beton bertulang dalam menahan beban aksial.

- Sampai berapa persen kekuatan tulangan cold formed type hollow dalam menahan beban aksial yang dapat dihasilkan terhadap tulangan baja konvensional pada elemen kolom beton bertulang.

Penelitian ini akan dilakukan pengujian beban aksial maximum sampai terjadi retak pada kolom beton bertulang dengan perencanaan tampang dua, ukuran kolom $20 \times 20 \times 60 \mathrm{~cm}$ dengan variabel dependen tulangan longitudinal baja ulir dan tulangan baja ringan type hollow. 


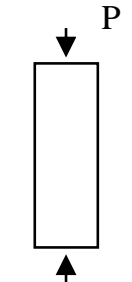

Gambar 1.1. : Benda uji yang dibebani secara aksial

Tujuan yang diharapkan dalam penelitian ini adalah mendapatkan kekuatan penggunaan tulangan cold formed pada elemen kolom beton bertulang, dan nantinya memberikan konstribusi dalam dunia pendidikan dan praktisi yang berkecimpung dalam dunia kontruksi berupa penggunaan alternatif bahan cold formed sebagai tulangan yang dapat dipergunakan selain baja tulangan konvensional.

\section{TINJAUAN PUSTAKA}

Beton dibentuk oleh pengerasan campuran semen, air, agregat halus, agregat kasar (batu pecah atau kerikil), udara, dan kadang - kadang adanya campuran tambahan lainnya. Campuran yang masih plastis ini dicor kedalam acuan dan dirawat untuk mempercepat reaksi hidrasi campuran semen - air, yang menyebabkan pengerasan beton. Bahan yang terbentuk ini mempunyai kekuatan tekan yang tinggi, dan ketahanan terhadap tarik yang rendah, atau kira - kira kekuatan tariknya 10 sampai 15 persen dari kekuatan terhadap tekan (Edward 1990). Maka penguatan terhadap tarik dan geser harus diberikan pada daerah tarik dari penampang untuk mengatasi kelemahan pada daerah tarik dari elemen beton bertulang. Kedua komponen ini, beton dan tulangan harus disusun komposisinya sehingga dapat dipakai sebagai material yang optimal.

Pada saat pembuatan beton diharapkan akan menjadi benda padat yang kuat tetapi harus diperhatikan bahwa pada kenyataan dilapangan sering kali pembuatan beton tidak menjadi seperti yang diharapkan karena timbulnya keretakan-keretakan yang terjadi akibat dari kondisi-kondisi yang mempengaruhi beton tersebut.

Beton mengalami keretakan karena beberapa sebab, sebab yang sering terjadi adalah karena adanya beban yang berlebih pada struktur tersebut sehingga beton mengalami retak pada daerah tarik yang dapat membahayakan struktur. Sebab lain yang sering terjadi adalah karena pengaruh temperatur yang menyebabkan susut dan rangkak pada beton.

\section{Kerusakan Pada Beton}

Beton bertulang dalam pelaksanaannya selalu memperhatikan keawetan dari struktur beton bertulang tersebut. Keawetan pada beton bertulang adalah sebagai kemampuan untuk menahan bekerjanya pengaruh kimia, fisika, dan mekanis.
Keawetan beton didasarkan atas dasar perencanaan, pelaksanaan dan pemakaian yang baik dan benar. Fase perencanaan terhadap beton bertulang adalah fase penting terhadap perencanaan kekakuan dan kekuatan serta menjadi acuan dari keawetan dari beton bertulang itu sendiri.

Pada struktur kolom sering terjadi retak yang diakibatkan oleh berlebihnya beban dari yang telah direncanakan, hal ini tentunya menyebabkan keawetan beton bertulang menjadi terganggu dan rusak. Penyebab beban berlebih ini diakibatkan oleh perubahan fungsi bangunan.

Masalah lain yang juga menjadi penyebab kerusakan pada beton biasanya diakibatkan oleh pelaksanaan dilapangan misalnya bentuk bekisting yang tidak kokoh, selimut beton yang tipis dan kurangnya perhatian pada sambungan pengecoran.

Kerusakan yang sering terjadi pada suatu struktur adalah timbulnya retak - retak pada bangunan yang akan mempengaruhi kekuatan dari beton bertulang bahkan memicu beton bertulang menjadi patah. Retak adalah suatu indikasi bahwa suatu struktur telah dipaksa untuk menerima atau menyerap energi dari suatu bentuk tegangan (Chemco System,2000).

Jenis kerusakan pada beton bertulang dapat dibagi dalam 3 pengaruh (Sagel dkk, Gideon, 1994) adalah :

1. Akibat pengaruh mekanis.

2. Akibat pengaruh fisika.

3. Akibat pengaruh kimia.

\section{Perencanaan Campuran Adukan Beton}

Metode perencanaan campuran beton yang dipergunakan adalah berdasarkan Standart Nasional Indonesia (SNI), Dasar perencanaan metode ini harus memenuhi persyaratan, yaitu :

1. Memenuhi ketentuan kuat tekan karakteristik atau kekuatan tekan minimum yang dikehendaki.

2. Memenuhi keawetan terhadap pengaruh pengaruh serangan agresif lingkungan.

3. Memenuhi kemudahan dalam pengerjaan dilapangan.

4. Memenuhi nilai ekonomis .

\section{Perencanaan tulangan kolom}

Resiko keruntuhan kolom lebih berbahaya di banding keruntuhan balok, karena kolom lebih banyak memikul bagian struktur di banding balok sehingga bila kolom runtuh akan lebih banyak bagian dari bangunan yang hancur di banding bila balok yang runtuh. Oleh karena itu dalam mendesain kolom harus mengandung dasar filosofi perencanaan kolom yaitu" strong column weak beam". 
Jenis kolom al :

- Kolom tekan pendek, seperti pedestal, umumnya beban aksial yang besar dan momen yang kecil atau diabaikan, kolom tipe ini bisa di desain tanpa tulangan walaupu penulangan hanya tulangan minimum.

- Kolom pendek , struktur yang kokoh dengan fleksibilitas yang kecil.

- Kolom langsing/panjang, dengan bertambahnya rasio kelangsingan deformasi lentur bertambah. Apabila kolom langsing menerima momen, sumbu akan

- Kolom sengkang spiral, kolom dengan tulangan dengan tulangan sengkang melingkar.

- Kolom komposit, kolom yang diberi tulangan longitudinal dangan profil baja struktur.

\section{Beban Axial Kolom Pendek}

Beban ultimate pada kolom tidak terlalu bervariasi terhadap sejarah pembebanannya. Pada saat beban bertambah, baja tulangan secara normal akan terjadi kekuatan lelehnya sebelum beton mencapai kehancuran. Bagaimanapun kondisi tersebut, kolom tidak dapat dikatakan terjadi beban ultimate. Beban axial ultimate yang terjadi pada kolom beton bertulang adalah gabungan dari kekuatan leleh baja tulangan dan kekuatan hancur beton. Kekuatan beton dengan beban axial pada kolom adalah sebesar 0,85 fc'. Sehingga beban ultimate untuk beban axial pada kolom dapat di rumuskan :

$$
P_{o}=0,85 \cdot f c^{\prime} \cdot\left(A_{g}-A_{s t}\right)+f_{y} \cdot A_{s t}
$$

\section{Dimana :}

$\mathrm{A}_{\mathrm{g}}$ : Luas kotor penampang kolom beton $\left(\mathrm{mm}^{2}\right)$

$\mathrm{A}_{\mathrm{st}}$ : Luas total baja tulangan longitudinal kolom ( $\mathrm{mm}^{2}$ )

$\mathrm{f}_{\mathrm{y}} \quad$ : Kuat leleh baja tulangan $\left(\mathrm{N} / \mathrm{mm}^{2}\right)$

fc' : Kuat tekan silinder beton $\left(\mathrm{N} / \mathrm{mm}^{2}\right)$

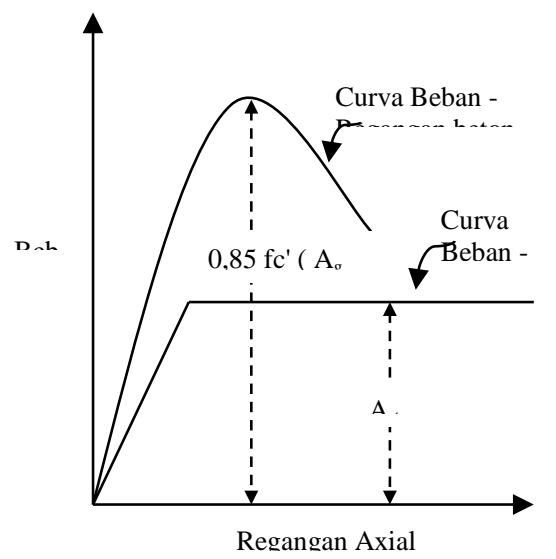

Gambar 2.3. Bentuk kurva hubungan beban - regangan untuk beton dan baja akibat beban axial kolom beton bertulang. berdefleksi secara lateral, akibanya akan ada beban tambahan yaitu beban kolom dikalikan defleksi lateral, hal ini disebut momen sekunder, atau momen $\mathrm{P} \Delta$.

- Kolom sengkang persegi, kolom dimana tulangan longitudinal di ikat oleh tulangan sengkang berbentuk persegi, tulangan sengkang mencegah tulangan longitudinal bergerak saat konstruksi dan mencegah tulangan longitudinal menekuk kearah luar pada saat menerima beban.

\section{Kondisi Baja Ringan Tulangan Pada Strain Hardening ( Pengerasan Regangan )}

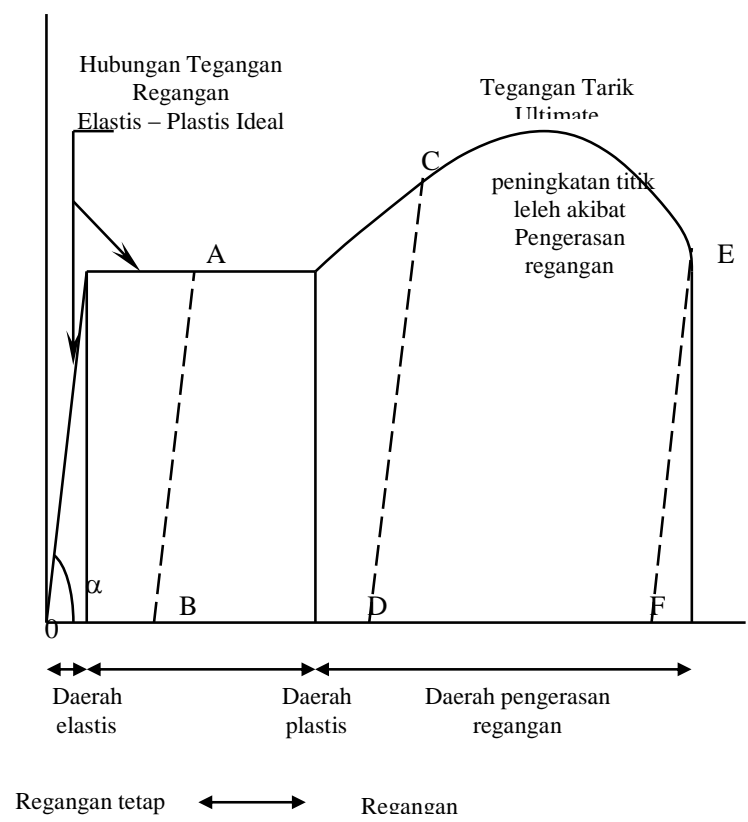

Gambar 2.4. Bentuk kurva ideal hubungan tegangan - regangan akibat adanya regangan yang melebihi pada daerah elastis. ( Charles G Salmon, Struktur Baja Desain dan Perilaku )

Pada gambar 2.4. memperlihatkan suatu sifat baja secara ideal, yang dapat dikatakan sebagai kurva perilaku mekanik tegangan - regangan baja. Pada saat batang baja diberikan pembebanan sampai suatu tegangan tertentu yang belum terjadi leleh, maka apabila pembebanan dilepaskan, batang baja akan kembali ke dalam keadaan semula, kembali ketitik 0, karena batang baja masih dalam daerah elastis. Apabila pembebanan dilakukan dan telah melampaui titik leleh ( yield point ) hingga ke titik $\mathrm{A}$, kemudian pembebanan dilepaskan, maka akan terjadi suatu regangan yang tertinggal atau regangan sisa sebesar $0 B$. pada kondisi ini kapasitas daktilitasnya atau banyaknya regangan tetapnya berkurang menjadi sebesar BF. Pembebanan kembali memperlihatkan seperti perilaku tegangan - regangan semula, tetapi dengan permulaan pembebanan pada titik $\mathrm{B}$, sehingga daerah plastis yang mendahului pengerasan regangan tersebut juga menjadi berkurang. Apabila 
batang baja diberikan pembebanan kembali yang dimulai dari titik B sampai pada titik C, pada saat pembebanan dilepaskan, maka kurva yang terjadi adalah titik CD. Titik $\mathrm{C}$ adalah menunjukkan suatu titik leleh sebagai akibat pengaruh pengerasan regangan ( strain hardening ), dengan tegangan yang lebih besar dari tegangan semula, dengan kata lain titik $\mathrm{C}$ dapat dikatakan sebagai peningkatan titik leleh akibat pengerasan regangan. Pada kondisi ini kapasitas daktilitasnya kembali berkurang tinggal sebesar DF. Dengan perilaku pembebanan berulang yang terjadi diluar daerah elastis akan dapat mengurangi tingkat daktilitas dari batang baja tulangan.

\section{METODE PENELITIAN}

\section{Diagram Alir Penelitian}

Secara umum tahapan penelitian dapat dijelaskan dalam diagram alir sebagai berikut :

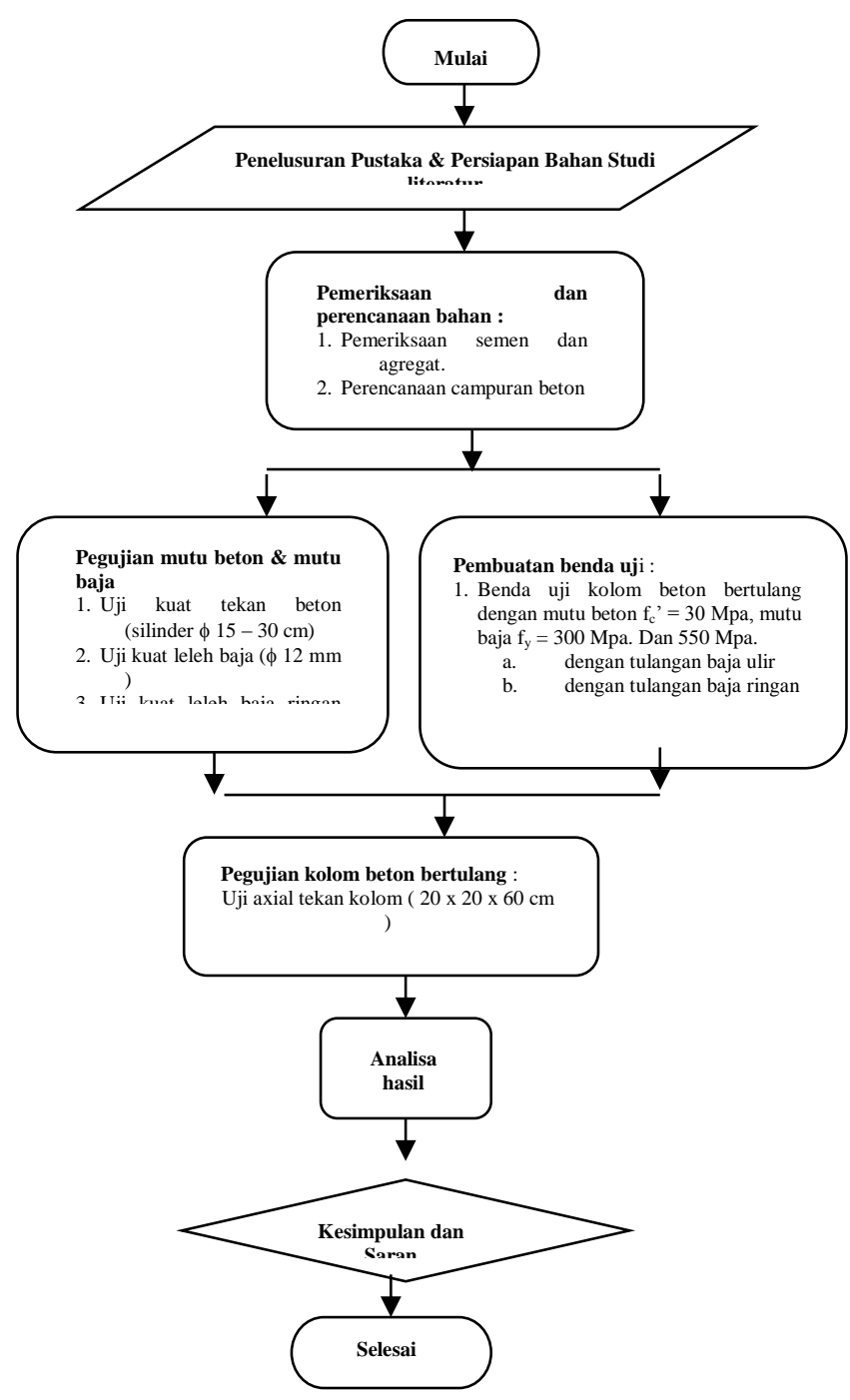

\section{Bahan dan Peralatan}

Bahan dan peralatan yang digunakan dalam penelitian adalah :

1. Benda uji silinder beton dimeter 15 $\mathrm{cm}$, panjang $30 \mathrm{~cm}$ sebanyak 20 buah.

2. Benda uji kolom beton bertulang dengan dimensi $20 \times 20 \times 60 \mathrm{~cm}$ sebanyak 3 buah kolom dengan tulangan longitudinal baja ulir $12 \mathrm{~mm}$, dan sebanyak 3 buah kolom dengan tulangan longitudinal baja ringan.

3. Cetakan beton ( begisting)

4. Mesin pengujian kuat tarik baja tulangan (Universal Testing Machine )

5. Mesin Pengujian kuat tekan silinder beton ( Universal Testing Machine )

6. Mesin pengujian kuat aksial ( Universal Testing Machine )

\section{Perencanaan dan Analisa Bahan}

Perencanaan awal kuat aksial kolom beton bertulang Perencanaan kuat aksial digunakan baja tulangan yang direncanakan dengan perencanaan tulangan tampang dua dengan kondisi underreinforced. Data data yang digunakan dalam perencanaan tulangan $\mathrm{sbb}$ :

$$
\begin{array}{ll}
\mathrm{fc}^{\prime} & =30 \mathrm{Mpa} \\
\mathrm{fy} & =300 \mathrm{Mpa} ; 550 \mathrm{Mpa} \\
\mathrm{b} & =200 \mathrm{~mm} \\
\mathrm{~h} & =200 \mathrm{~mm} \\
\mathrm{l} & =600 \mathrm{~mm} \\
\text { deking } \quad=40 \mathrm{~mm}
\end{array}
$$

tul longitudinal $=4-\phi 12 \mathrm{~mm}$;

$$
4-40 ; 20 ; 0,5 \mathrm{~mm}
$$

tul geser $\quad=\phi 6 \mathrm{~mm}-60 \mathrm{~mm}$

\section{Penyelidikan bahan semen dan agregat}

Penyelidikan atau pemeriksaan bahan pembentuk beton yaitu bahan semen dan agregat bertujuan untuk mengetahui kondisi masing-masing bahan sehingga dapat dipergunakan dalam merencanakan campuran adukan beton yang sesuai dengan kuat tekan beton yang diharapkan. Bahan semen menggunakan semen gresik type I, bahan agregat kasar berupa batu pecah dan agregat halus alami dari mojokerto.

\section{Perencanaan campuran adukan beton}

Campuran adukan beton direncanakan dengan menggunakan metode SNI ( Standart Nasional Indonesia ), yang direncanakan mempunyai kuat tekan beton 30 Mpa pada umur 28 hari dengan bagian cacat $5 \%$.

\section{Pengujian bahan}

\section{Pengujian kuat tekan beton fc'}

Pengujian kuat tekan dilakukan terhadap sample benda uji silinder diameter $15 \mathrm{~cm}$ dan tinggi $30 \mathrm{~cm}$, sebanyak 4 buah untuk masing-masing umur 3, 7, 14, 21, 28 hari. Dari hasil pengujian ini akan didapatkan nilai kuat tekan 
beton fc' untuk benda uji balok beton bertulang dan digunakan sebagai perencanaan kuat lentur yang dicapai oleh benda uji balok beton bertulang.

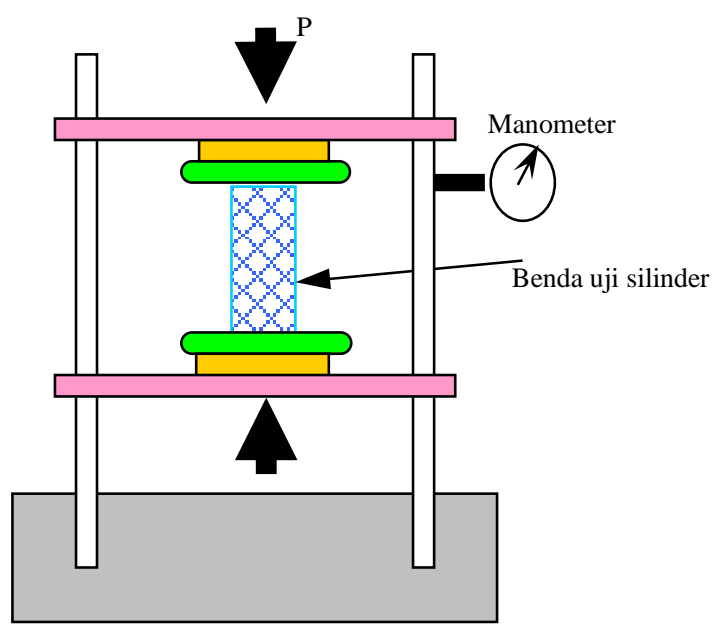

Gambar 3.1. Model Pengujian Kuat tekan beton

\section{Pengujian kuat leleh baja tulangan fy}

Pengujian dilakukan terhadap sample benda uji baja tulangan produksi master steel yang mempunyai kuat leleh spesifikasi $400 \mathrm{Mpa}$ dengan diameter $12 \mathrm{~mm}$ sebanyak 4 buah, baja ringan type hollow produksi smart truss yang mempunyai kuat leleh $550 \mathrm{Mpa}$ dengan ukuran 40,20,1 mm sebanyak 4 buah. Pengujian kuat leleh baja tulangan dilakukan dengan menarik benda uji baja tulangan hingga putus, yang nantinya dapat diketahui nilai kuat leleh dan kuat tarik baja tulangan serta grafik tegangan - regangan dari baja tulangan. Dari hasil pengujian kuat leleh dan kuat tarik aktual ini nantinya digunakan sebagai perencanaan kuat lentur yang dicapai oleh benda uji balok beton bertulang.

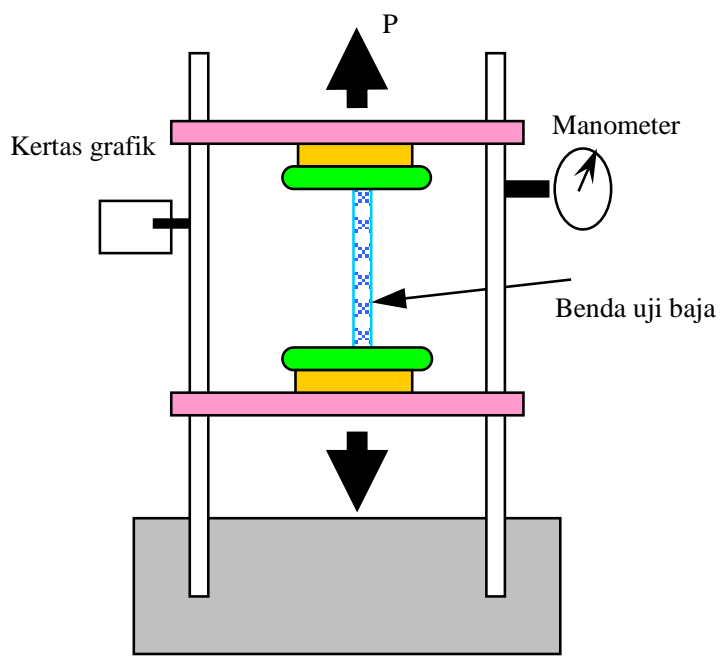

\section{Pembuatan benda uji \\ Detail penampang kolom beton bertulang}
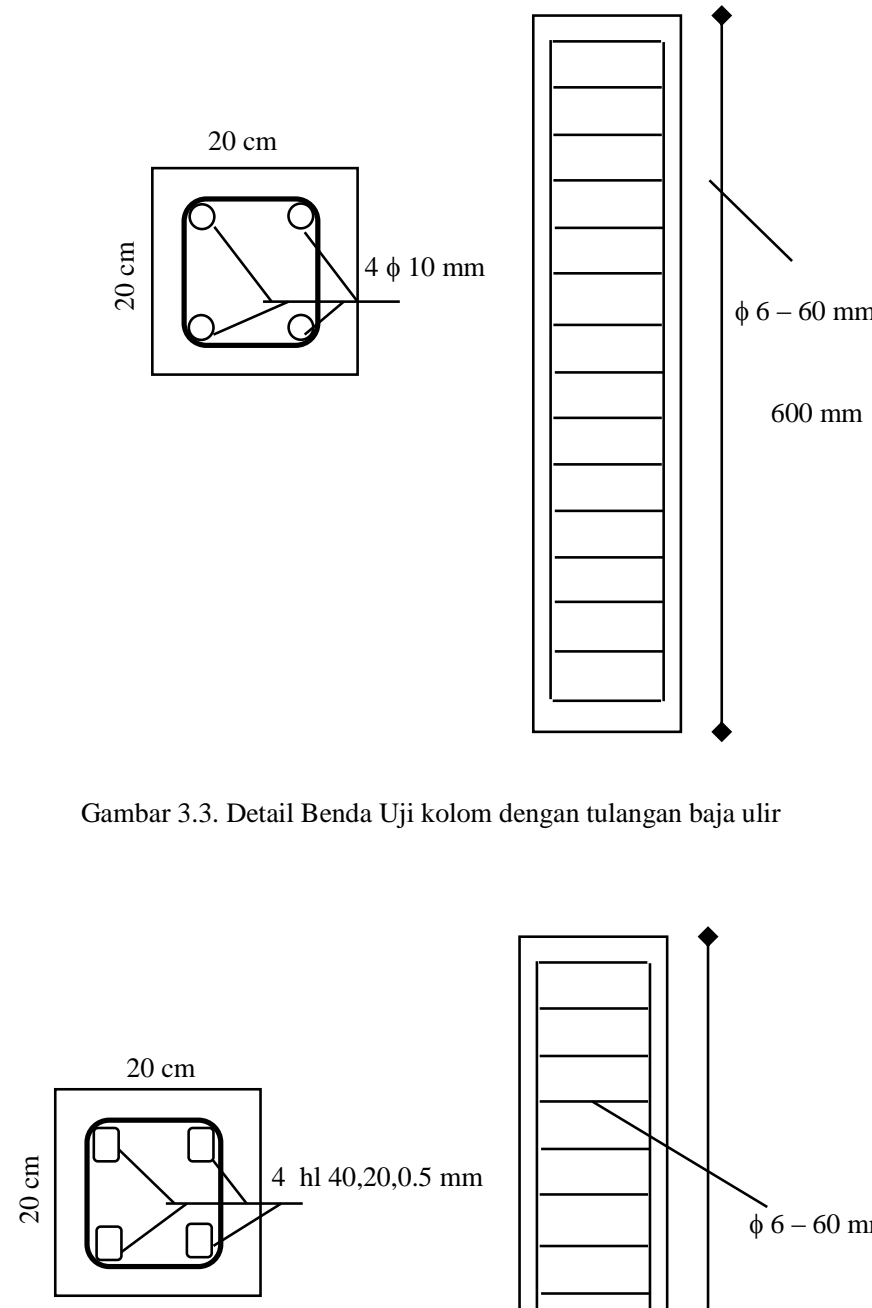

Gambar 3.3. Detail Benda Uji kolom dengan tulangan baja ulir

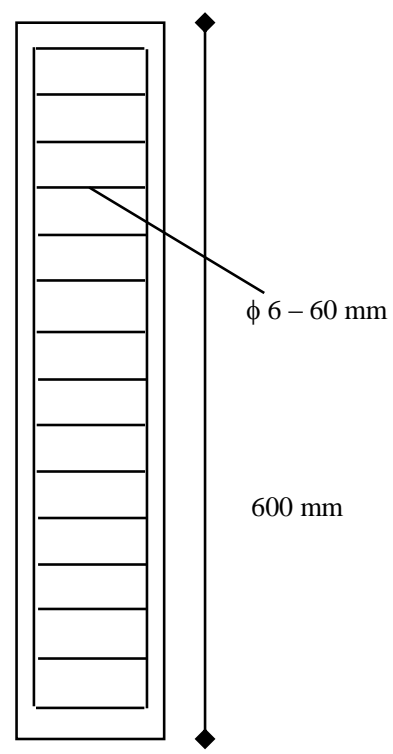

Gambar 3.4. Detail Benda Uji kolom dengan tulangan baja ringan 


\section{Detail Jenis Pengujian}

Pembebanan dilaksanakan dengan pemberian beban langsung dengan dua titik terpusat dari tengah bentang. Alat yang digunakan adalah Universal Testing Machine (UTM) dengan kapasitas 100 ton, dengan kecepatan pembebanan antara 862 sampai $1207 \mathrm{kPa} /$ menit, sesuai standart ASTM.

Kekuatan Aksial kolom dapat diketahui dengan persamaan :

$P_{o}=0,85 \cdot f c^{\prime} \cdot\left(A_{g}-A_{s t}\right)+f_{y} \cdot A_{s t}$

dimana :

Pn : Kapasitas pembebanan nominal kolom ( N )

$\mathrm{Ag} \quad$ : Luas kotor kolom $\left(\mathrm{mm}^{2}\right)$

Ast : Luas tulangan longitudinal $\left(\mathrm{mm}^{2}\right)$

Fc' : Kuat tekan silinder beton $\left(\mathrm{N} / \mathrm{mm}^{2}\right)$

fy : Kuat leleh Baja tulangan $\left(\mathrm{N} / \mathrm{mm}^{2}\right)$

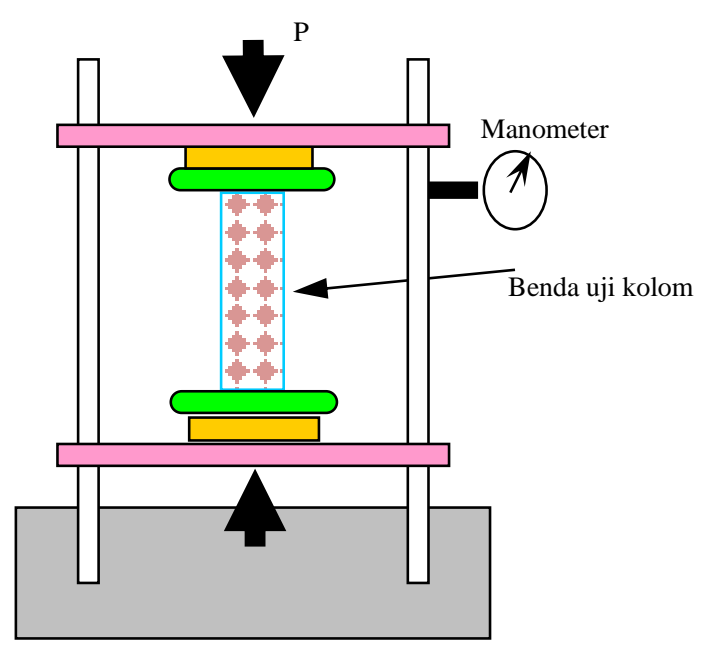

Gambar 3.4. Model pengujian kuat aksial kolom beton bertulang

\section{HASIL DAN PEMBAHASAN}

Dalam bab ini akan disajikan beberapa hasil dari pengujian - pengujian yang telah dilakukan terhadap material beton, baja tulangan dan uji axial kolom beton bertulang. Berikut analisa dan pembahasannya.

\section{Hasil Pemeriksaan Material Beton ( Semen dan Agregat )}

Semua material pembentuk beton, yaitu semen, agregat halus dan agregat kasar sebelum dipergunakan dalam pembuatan beton dilakukan pemeriksaan kondisi material di Labobratorium.

Adapun setelah dilakukan pemeriksaan terhadap material pembentuk beton, maka beberapa hasil yang didapatkan adalah sebagai berikut :
Tabel .4.1. Hasil pengujian material beton

\begin{tabular}{|c|c|c|}
\hline No. & Jenis Pemeriksaan bahan & Nilai yang dihasilkan \\
\hline 1 & Berat Jenis Semen & $3.15 \mathrm{gr} / \mathrm{cm}^{3}$ \\
\hline \multirow[t]{3}{*}{2} & Berat volume Semen & \\
\hline & Tanpa rojokan / lepas & $1.16 \mathrm{gr} / \mathrm{cm}^{3}$ \\
\hline & Dengan rojokan & $1.28 \mathrm{gr} / \mathrm{cm}^{3}$ \\
\hline \multirow[t]{3}{*}{3} & Berat Volume Agregat Halus & \\
\hline & Tanpa rojokan / lepas & $1.55 \mathrm{gr} / \mathrm{cm}^{3}$ \\
\hline & Dengan rojokan & $1.63 \mathrm{gr} / \mathrm{cm}^{3}$ \\
\hline \multirow[t]{4}{*}{4} & Berat Jenis Agregat Halus & \\
\hline & Basah / asli & $2.79 \mathrm{gr} / \mathrm{cm}^{3}$ \\
\hline & Kering Permukaan / SSD & $2.55 \mathrm{gr} / \mathrm{cm}^{3}$ \\
\hline & Kering Oven & $2.32 \mathrm{gr} / \mathrm{cm}^{3}$ \\
\hline 5 & Penyerapan Air Agregat Halus & $4.30 \%$ \\
\hline \multirow[t]{2}{*}{6} & Kadar Air Agregat Halus & \\
\hline & Kering Permukaan / SSD & $5.20 \%$ \\
\hline 7 & Kadar Lumpur Agregat Halus & $3.50 \%$ \\
\hline 8 & Kadar organik agregat halus & Warna coklat muda \\
\hline 9 & Gradasi Agregat Halus & Grade Zone 2 \\
\hline \multirow[t]{3}{*}{10} & Berat Volume Agregat Kasar & \\
\hline & Tanpa rojokan / lepas & $1.65 \mathrm{gr} / \mathrm{cm}^{3}$ \\
\hline & Dengan rojokan & $1.75 \mathrm{gr} / \mathrm{cm}^{3}$ \\
\hline \multirow[t]{4}{*}{11} & Berat Jenis Agregat Kasar & \\
\hline & Basah / asli & $2.7 \mathrm{gr} / \mathrm{cm}^{3}$ \\
\hline & Kering Permukaan / SSD & $2.67 \mathrm{gr} / \mathrm{cm}^{3}$ \\
\hline & Kering Oven & $2.61 \mathrm{gr} / \mathrm{cm}^{3}$ \\
\hline 12 & Penyerapan Air Agregat Kasar & $1.50 \%$ \\
\hline \multirow[t]{2}{*}{13} & Kadar Air Agregat Kasar & \\
\hline & Kering Permukaan / SSD & $1.20 \%$ \\
\hline 14 & Kadar Lumpur Agregat Kasar & $0.95 \%$ \\
\hline 15 & Gradasi Agregat Kasar & $3 / 16$ in $s / d 1 / 2$ in \\
\hline
\end{tabular}

\section{Perencanan Campuran Beton ( Mix Desain )}

Perencanaan campuran adukan beton dengan menggunakan metode SNI. Dalam perencanaan campuran ini berdasarkan dari hasil pemeriksaan material dan diharapkan dapat menghasilkan mutu beton yang diharapkan yaitu mutu $30 \mathrm{Mpa}$. Prosedur perencanaan campuran beton dapat ditabelkan sbb : 
Tabel 4.2. Rancangan Adukan Beton

DAFTAR ISIAN ( FORMULIR ) PERENCANAAN CAMPURAN BETON "STANDART NASIONAL INDONESIA"

\begin{tabular}{|c|c|c|c|}
\hline No. & URAIAN & $\begin{array}{l}\text { TABEL/GRAFIK/ } \\
\text { PERHITUNGAN }\end{array}$ & NILAI \\
\hline 1 & Kuat tekan yang disyaratkan & $\begin{array}{l}\text { Ditetapkan pada umur } 28 \text { hari } \\
\text { dengan bagian cacat } 5 \%\end{array}$ & $30 \mathrm{Mpa}$ \\
\hline & & & $357 \mathrm{Kg} / \mathrm{cm}^{2}$ \\
\hline 2 & Deviasi Standart & Diketahui atau tabel 2.1 & 5.882352941 Mpa \\
\hline & & & $60 \mathrm{Kg} / \mathrm{cm}^{2}$ \\
\hline 3 & Nilai Tambah (margin) & $\mathrm{k}=1,64 \times \mathrm{Sr}$ & $9.647058824 \mathrm{Mpa}$ \\
\hline & & & $98.4 \mathrm{Kg} / \mathrm{cm}^{2}$ \\
\hline 4 & Kekuatan rata - rata yang direncanakan & $1+3$ & $44.64705882 \mathrm{Mpa}$ \\
\hline & & & $455.4 \mathrm{Kg} / \mathrm{cm}^{2}$ \\
\hline 5 & Jenis semen & Ditetapkan & Semen Normal Type I \\
\hline & & & S550 \\
\hline 6 & Jenis agregat kasar & & Batu Pecah \\
\hline & Jenis agregat halus & & Alami \\
\hline 7 & Faktor air semen bebas & Tabel 2.2 dan grafik 2.1 & 0.44 \\
\hline 8 & Faktor air semen maximum & Ditetapkan atau PBI atau tabel 2.3 & 0.52 \\
\hline 9 & Slump & Ditetapkan atau PBI & $80 \mathrm{Mm}$ \\
\hline 10 & Ukuran agregat maximum & Ditetapkan atau PBI & $30 \mathrm{Mm}$ \\
\hline & & & \\
\hline 11 & Kadar air bebas & Tabel 2.4 & $184.9 \mathrm{liter} / \mathrm{m}^{3}$ \\
\hline 12 & Jumlah semen & $11: 7$ atau $11: 8$ & $420.2272727 \mathrm{~kg} / \mathrm{m}^{3}$ \\
\hline 13 & Jumlah semen maximum & Ditetapkan & $420.2272727 \mathrm{~kg} / \mathrm{m}^{3}$ \\
\hline & & & \\
\hline 14 & Jumlah semen minimum & Ditetapkan atau PBI atau tabel 2.3 & $325 \mathrm{~kg} / \mathrm{m}^{3}$ \\
\hline 15 & Faktor air yang disesuaikan & & 0.44 \\
\hline & & & \\
\hline 16 & Susunan besar butir agregat halus & & Zone 2 \\
\hline 17 & Prosentase bahan lebih halus dari $4.8 \mathrm{~mm}$ & Grafik $2.6 \mathrm{~s} / \mathrm{d} 2.8$ & $35 \%$ \\
\hline & & & 0.35 \\
\hline 18 & $\begin{array}{l}\text { Berat jenis riil agregat } \\
\text { (kering permukaan ) }\end{array}$ & & 2.6 \\
\hline
\end{tabular}

\begin{tabular}{|c|l|l|c|}
\hline No. & \multicolumn{1}{|c|}{ U R A I A N } & $\begin{array}{c}\text { TABEL/GRAFIK/ } \\
\text { PERHITUNGAN }\end{array}$ & NILAI \\
\hline 19 & Berat Jenis Beaten & Grafik 2.9 & $2370 \mathrm{~kg} / \mathrm{m}^{3}$ \\
\hline 20 & & & \\
\hline & Kadar agregat Gabungan & $19-11-12$ & $1764.873 \mathrm{~kg} / \mathrm{m}^{3}$ \\
\hline 21 & Kadar agregat halus & $17 \times 20$ & $617.705 \mathrm{~kg} / \mathrm{m}^{3}$ \\
\hline 22 & \multicolumn{2}{|l}{} & $1147.167 \mathrm{~kg} / \mathrm{m}^{3}$ \\
\hline 2 & Kadar agregat kasar & $20-21$ & \\
\hline $\begin{array}{l}\text { Kesimpulan kebutuhan campuran per m } \\
\text { Semen }\end{array}$ & & $420.227 \mathrm{~kg}$ \\
\hline
\end{tabular}

Hasil Pengujian kuat leleh baja tulangan a. Kuat leleh \& kuat tarik baja tulangan ulir dia $\mathbf{1 2}$ mm
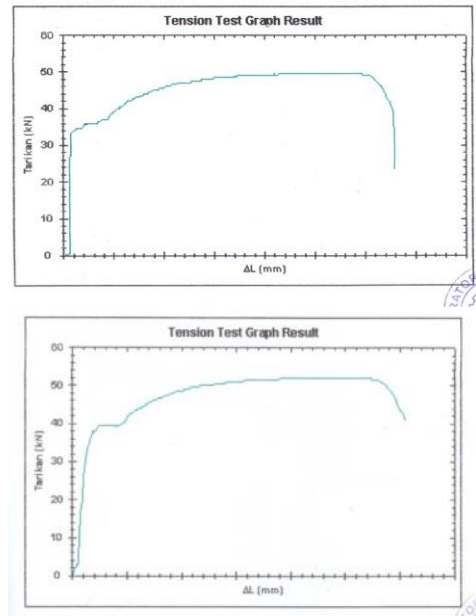

b. Kuat leleh \& kuat tarik baja cold formed 40;20;0,5 mm
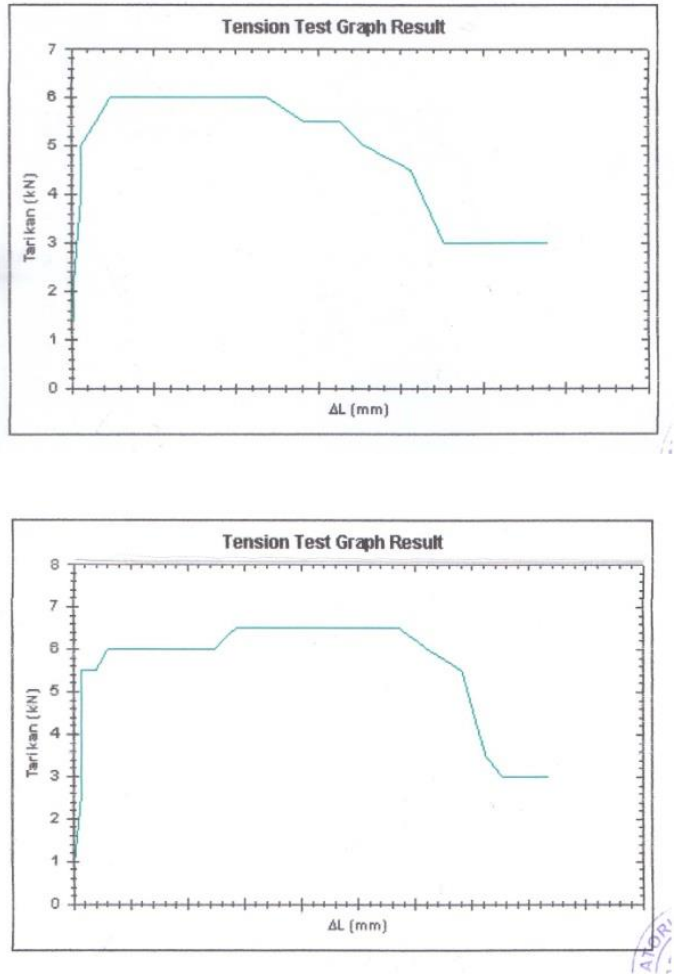

Kesimpulan hasil pengujian kuat tarik baja :

1. Hasil dari pengujian baja tulangan ulir dia $12 \mathrm{~mm}$ menghasilkan kuat leleh rata-rata sebesar $283 \mathrm{~N} / \mathrm{mm}^{2}$ dan kuat tarik sebesar $442 \mathrm{~N} / \mathrm{mm}^{2}$.

2. Hasil pengujian baja cold formed $40 \times 20 \times 0,5$ menghasilkan kuat leleh rata-rata sebesar $135 \mathrm{~N} / \mathrm{mm}^{2}$ dan kuat tarik sebesar $165 \mathrm{~N} / \mathrm{mm}^{2}$

Berdasarkan dari hasil pengujian kuat tarik baja tulangan menunjukkan kekuatan aktual yang terjadi jauh lebih rendah dari nilai kekuatan teoritis perencanannya, sehingga dalam hal ini dapat berpengaruh pada nilai kekuatan axial pada kolom.

\section{Rencana kekuatan spesifikasi axial kolom}

a. Tulangan baja ulir dia $12 \mathbf{~ m m}$

$$
P_{o}=0,85 \times f c^{\prime} x\left(A_{g}-A_{s t}\right)+f_{y} \cdot A_{s t}
$$$$
P_{o}=0,85 \times 30 \times(40000-452)+300 \times 452
$$$$
P_{o}=1.008 .474+127.916
$$$$
P_{o}=1.144 .074 \mathrm{~N}
$$

$$
\begin{aligned}
& \text { b. Tulangan baja cold-formed 40x20x0,5 mm } \\
& P_{o}=0,85 \times f c^{\prime} \times\left(A_{g}-A_{s t}\right)+f_{y} \cdot A_{s t} \\
& P_{o}=0,85 \times 30 \times(40.000-156)+550 \times 156 \\
& P_{o}=1.016 .051+20.903 \\
& P_{o}=1.101 .822 \mathrm{~N}
\end{aligned}
$$


Berdasarkan perhitungan rencana kekuatan spesifikasi pada kolom yang menggunakan tulangan baja ulir $12 \mathrm{~mm}$ menunjukkan mempunyai kekuatan axial lebih tinggi 3,7 \% dari kolom dengan menggunakan tulangan baja cold-form. Perbedaan kekuatan tersebut dipengaruhi oleh besarnya luas tulangan dan besarnya kuat leleh baja tulangan yang digunakan dalam kolom.

\section{Hasil uji kuat tekan beton dengan menggunakan Hammer test}

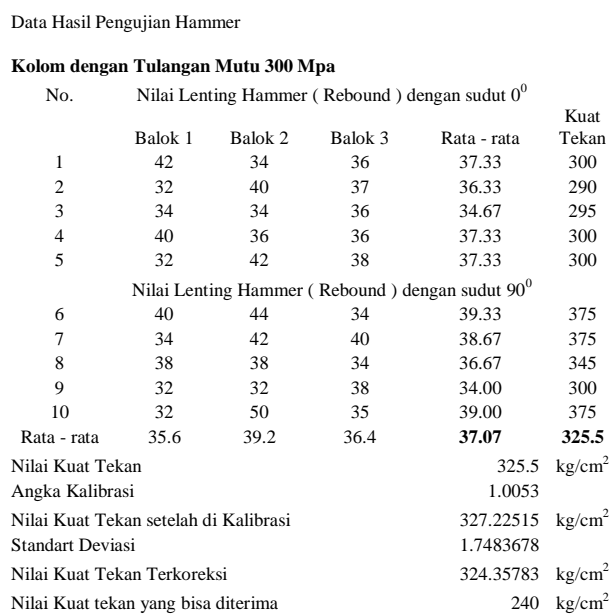

Berdasarkan hasil pengujian kuat tekan beton dengan menggunakan hammar test, kekuatan tekan beton untuk kolom dengan tulangan baja ulir sebesar $324,36 \mathbf{~ k g} / \mathrm{cm}^{2}$, sedangkan kekuatan tekan beton (fc') untuk kolom dengan tulangan cold-formed menghasilkan lebih rendah dari kolom dengan tulangan baja ulir yaitu sebesar $217,21 \mathrm{~kg} / \mathrm{cm}^{2}$.
Hasil uji axial tekan kolom beton dengan menggunakan Universal Testing Mesin

Hasil uji axial kolom

Kolom dengan mengggunakan tulangan baja ulir

\begin{tabular}{|c|c|c|c|c|c|c|c|c}
\hline $\begin{array}{c}\text { No. } \\
\text { Balok }\end{array}$ & $\begin{array}{c}\mathrm{b} \\
(\mathrm{mm})\end{array}$ & $\begin{array}{c}\mathrm{h} \\
(\mathrm{mm})\end{array}$ & $\begin{array}{c}\mathrm{Ag} \\
\left(\mathrm{mm}^{2}\right)\end{array}$ & $\begin{array}{c}\mathrm{fc}^{\prime} \\
\left(\mathrm{N}^{\prime} \mathrm{mm}^{2}\right)\end{array}$ & $\begin{array}{c}\text { Ast } \\
\left(\mathrm{mm}^{2}\right)\end{array}$ & $\begin{array}{c}\mathrm{fy} \\
\left(\mathrm{Nmm}^{2}\right)\end{array}$ & $\begin{array}{c}\text { Kekuatan Teoritis } \mathrm{P}_{\mathbf{0}} \\
(\mathbf{N})\end{array}$ & $\begin{array}{c}\text { Kekuatan Axial aktual P } \\
(\mathrm{N})\end{array}$ \\
\hline \hline 1 & 200 & 200 & 40000 & 32.5 & 452 & 283 & 1220429.5 & 116800 \\
\hline 2 & 200 & 200 & 40000 & 32.5 & 452 & 283 & 1220429.5 & 86400 \\
\hline 3 & 200 & 200 & 40000 & 32.5 & 452 & 283 & 1220429.5 & 96200 \\
\hline
\end{tabular}

Hasil uji axial kolom

Kolom dengan mengggunakan tulangan cold-formed

\begin{tabular}{|c|c|c|c|c|c|c|c|c|}
\hline $\begin{array}{c}\text { No. } \\
\text { Balok }\end{array}$ & $\mathbf{b}(\mathbf{m m})$ & $\begin{array}{c}\mathrm{h} \\
(\mathrm{mm})\end{array}$ & $\begin{array}{c}\mathrm{Ag} \\
\left(\mathrm{mm}^{2}\right)\end{array}$ & $\begin{array}{c}\mathrm{fc}^{\prime} \\
\left(\mathbf{N} / \mathrm{mm}^{2}\right)\end{array}$ & $\begin{array}{c}\text { Ast } \\
\left(\mathrm{mm}^{2}\right)\end{array}$ & $\begin{array}{c}\text { fy } \\
\left(\mathbf{N} / \mathrm{mm}^{2}\right)\end{array}$ & $\begin{array}{c}\text { Kekuatan Teoritis } \mathbf{P}_{\mathbf{0}} \\
(\mathbf{N})\end{array}$ & $\begin{array}{c}\text { Kekuatan Axial aktual P } \\
(\mathbf{N})\end{array}$ \\
\hline \hline 1 & 200 & 200 & 40000 & 21.7 & 156 & 135 & 755982.58 & $\mathbf{5 1 4 0 0 0}$ \\
\hline 2 & 200 & 200 & 40000 & 21.7 & 156 & 135 & 755982.58 & 428000 \\
\hline 3 & 200 & 200 & 40000 & 21.7 & 156 & 135 & 755982.58 & 516000 \\
\hline
\end{tabular}

Perbandingan kekuatan untuk kolom dengan tulangan baja ulir

\begin{tabular}{|c|c|c|c}
\hline Kekuatan Spesifikasi $\mathbf{P}_{\mathbf{0}}(\mathbf{N})$ & Kekuatan Teoritis $\mathbf{P}_{\mathbf{0}}(\mathbf{N})$ & Kekuatan Axial aktual $\mathbf{P}(\mathbf{N})$ & Aktual terhadap teoritis $(\%)$ \\
\hline \hline 1.144 .074 & $1.220 .429,5$ & 988.000 & $\mathbf{1 9 . 0 4}$ \\
\hline 1.144 .074 & $1.220 .429,5$ & 864.000 & $\mathbf{2 9 . 2 1}$ \\
\hline 1.144 .074 & $1.220 .429,5$ & 962.000 & $\mathbf{2 1 . 1 8}$ \\
\hline
\end{tabular}

Perbandingan kekuatan untuk kolom dengan tulangan baja cold-formed

\begin{tabular}{|c|c|c|c}
\hline Kekuatan Spesifikasi $\mathbf{P}_{\boldsymbol{0}}(\mathbf{N})$ & Kekuatan Teoritis $\mathbf{P}_{\mathbf{0}}(\mathbf{N})$ & Kekuatan Axial aktual $\mathbf{P}(\mathbf{N})$ & Aktual terhadap teoritis $(\%)$ \\
\hline \hline 1.101 .822 & $755.982,58$ & 514.000 & 32.01 \\
\hline 1.101 .822 & $755.982,58$ & 528.000 & 30.16 \\
\hline 1.101 .822 & $755.982,58$ & 516.000 & 31.74 \\
\hline
\end{tabular}

Setelah dilakukan pengujian axial menunjukkan pada kolom dengan menggunakan tulangan baja ulir nilai kekuatan aktual axial kolom yang lebih rendah $23,14 \%$ terhadap kekuatan teoritinya, sedangkan pada kolom dengan menggunakan tulangan baja cold-formed juga menghasilkan nilai kekuatan aktual axial kolom yang lebih rendah $31,30 \%$ terhadap kekuatan teoritisnya. Berdasarkan dari hasil pengujian axial kolom menunjukkan bahwa kolom mempunyai kecenderungan keruntuhan lebih besar, maka nilai faktor reduksi kekuatannya juga lebih rendah. Dari hasil pengujian kolom dengan menggunakan tulangan baja ulir, untuk nilai faktor reduksi kekuatan $(\phi)$ sebesar 0,7, sedangkan pada kolom dengan menggunakan tulangan baja cold-formed, untuk nilai faktor reduksi kekuatan $(\phi)$ lebih tinggi yaitu sebesar 0,6.

Penggunaan kolom dengan menggunakan tulangan baja ulir dalam penelitian ini masih lebih efektif dari pada dengan menggunakan tulangan baja cold-formed. Kolom dengan tulangan baja col-formed mempunyai kekuatan lebih rendah 44, $4 \%$ dari kolom dengan menggunakan tulangan baja ulir. 


\section{KESIMPULAN DAN SARAN}

Kesimpulan dalam penelitian ini antara lain :

1. Hasil dari pengujian baja tulangan ulir dia $12 \mathrm{~mm}$ menghasilkan kuat leleh rata-rata sebesar $283 \mathrm{~N} / \mathrm{mm}^{2}$ dan kuat tarik sebesar $442 \mathrm{~N} / \mathrm{mm}^{2}$.

2. Hasil pengujian baja cold formed $40 \times 20 \times 0,5$ menghasilkan kuat leleh rata-rata sebesar $135 \mathrm{~N} / \mathrm{mm}^{2}$ dan kuat tarik sebesar $165 \mathrm{~N} / \mathrm{mm}^{2}$.

3. Berdasarkan perhitungan rencana kekuatan spesifikasi pada kolom yang menggunakan tulangan baja ulir $12 \mathrm{~mm}$ menunjukkan mempunyai kekuatan axial lebih tinggi $3,7 \%$ dari kolom dengan menggunakan tulangan baja cold-form

4. Berdasarkan hasil pengujian kuat tekan beton dengan menggunakan hammar test, kekuatan tekan beton untuk kolom dengan tulangan baja ulir sebesar $324,36 \mathbf{~ k g} / \mathrm{cm}^{2}$, sedangkan kekuatan tekan beton (fc') untuk kolom dengan tulangan cold-formed menghasilkan lebih rendah dari kolom dengan tulangan baja ulir yaitu sebesar $217,21 \mathrm{~kg} / \mathrm{cm}^{2}$.

5. Penggunaan kolom dengan menggunakan tulangan baja ulir dalam penelitian ini masih lebih efektif dari pada dengan menggunakan tulangan baja cold-formed. Kolom dengan tulangan baja col-formed mempunyai kekuatan lebih rendah $44,4 \%$ dari kolom dengan menggunakan tulangan baja ulir.

Saran dalam penelitian ini :

1. Dalam rangka perkembangan teknologi konstruksi yang terus berkembang dan dituntut untuk penggunaan bahan yang ringan tetapi mempunyai kekuatan yang tinggi serta bahan yang ramah lingkungan, maka dengan hasil penelitian ini nantinya dapat digunakan sebagai penelitian lebih lanjut, yaitu tulangan cold-formed bentuk hollow yang yang diisi beton

2. Penggunaan baja ringan dengan tipe yang lain sebagai tulangan pada elemen struktur beton bertulang.

\section{DAFTAR PUSTAKA}

- Wei-Wen Yu, Ph.D., P.E. 2000, “ COLDFORMED STEEL DESIGN “, John Wiley \& Sons, Inc.

- ASTM, 2003, “A 370-03a , “ Standard Test Methods and Definition for Mechanical Testing of steel Products ", USA.

- SNI-2847-2002, “ Tata Cara Perhitungan Struktur Beton untuk Bangunan Gedung ”, ITS press

- American Iron and Steel Institute, (2002), “ AISI Manual ", 2002 Edition, USA.

- Ferguson, Phill M, 2006, “ Reinforced Concrete Fundamentals ", The University of Texas at Austin, John Wiley \& Sons, Inc.
- Nawy Edward G,2005, " Reinforced Concrete A

Fundamental Approach “, Prentice hall Inc.

- R.Park and T. Paulay, 1975, “ Reinforced

Concrete Structures ", University of Canterbury,Christchurch,New Zealand, John Wiley \& Sons, Inc.

- Paul Nugraha, Antoni, 2007 "Teknologi Beton ", Universitas Kristen Petra

- Wira et al, 2005, “ Struktur Baja Disain dan perilaku “, Bandung Erlangga 